\title{
Experimental Analysis of a Diesel Engine Run on Different Biodiesel Fuel Blends
}

\author{
Vidya Sagar Mishra1, Dr. Nitin Tenguria² \\ ${ }^{1}$ Research Scholar, ${ }^{2}$ Associate Professor \\ 1,2Department of Mechanical Engineering, Sagar Institute of Research \& Technology, \\ Bhopal, Madhya Pradesh, India
}

\begin{abstract}
Ever increasing rate in the production of automotive vehicles and the significance of decreasing the pollutions in nature trigger numerous researches to find the alternative solution. Biodiesel has been considered a vital fuel for diesel engine view point. In the present study a single cylinder diesel engine was run fully on non-petroleum fuels blends. In this regard Jatropha methyl ester (JME) and waste transformer oil (WTO) were selected as a fuel for the replacement of diesel. diesel engines such as fuel direct injection method is used. The WTO at low percentages (10-40\% at regular intervals of $10 \%$ on a volume basis), was blended with diesel, to get the fuel blends for the investigation. The performance and emission terms were compared, analyzed and presented in this article.
\end{abstract}

Keywords: Biodiesel; Diesel Engine; Waste to Energy; Efficiency

\section{INTRODUCTION}

Fast depletion of fossil fuels and increasing number of vehicle population, and their detrimental effect on the environment results in urgent need of alternative fuels for meeting the sustainable energy demand with minimum environmental impact [1]. Therefore, there is a necessity to find suitable alternative fuels for diesel engines that are cheaper and eco-friendly. Biomass is a very good source for deriving different kind of alternative fuels. Biomass is available in the form of agriculture residue, vegetable seeds, animal waste, crop residue, food waste, industrial waste, municipal waste etc [2]. Biomass is an organic matter and is renewable over time. There are two methods commonly adopted to derive alternative fuels from biomass sources which are; (i) Biochemical method (ii) Thermo-chemical method. In biochemical method, fermentation and anaerobic digestion are used to convert some of the biomass wastes into alcohol and biogas respectively. Biomass sources such as crop residue, cow dung, pig manure, spent wash etc. are converted into biogas through anaerobic digestion. If the biomass source is properly converted into an alternative fuel especially for diesel engine, then the demand for diesel fuel will be considerably reduced [3-5].

Energy consumption is growing exponentially due to rapid progress in the population, industrialization and increase in number of automotive vehicle. Nowadays, the petroleum fuels play a vital role in the mobility, industrial sectors, and agricultural sectors. Meanwhile, the availability of petroleum resources is limited in nature, available in restricted area and they are getting depleted day by day [6-10 Furthermore, problems related to the environment are the most important consequences of consumption of more petroleum fuels. The issue of energy security and environment issues made countries and researchers to look for alternate means of renewable as well as environment-friendly fuels. The most promising and economically viable alternative fuels which can be a replacement of petroleum fuels are biofuels [11-13]. Various sectors are looking for alternative fuels because of the energy crisis and the fear of society for depleting earth's non-renewable resources. Among various researchers from all over the world started proposing various methods to use vegetable oils in internal combustion engines. These methods include pyrolysis, micro-emulsification, direct blending with diesel, transesterification. etc. [14-15].

Engine test [16] was conducted using Putranjiva, Jatropha and Karanja oils in a Ricardo variable compression ignition engine to investigate and compare the results of performance and emission properties. It was found that the non-edible oil of Jatropha gave the best performance and emissions results at all the load conditions compared with other vegetable oils. Saravanan et al [17] have investigated the feasibility study of crude rice bran oil as a diesel substitute in a compression ignition engine without any modifications. They reported that thermal efficiency of the engine with rice bran oil is slightly lesser than diesel, but resulted in better emission characteristics. Naga Prasad et al. [18] investigated the compression ignition engine with neat castor oil and its blends with diesel and found that the performance characteristics are reduced to those of diesel. But they also found that the emission characteristics are increased at the rated load compared to those of diesel. Also, they observed that $25 \%$ of neat Castor oil blended with $75 \%$ of diesel is the well-suited blend for Diesel engine without heating and/or without implementing any engine modifications. Deepanraj etal., [19] studied the performance characteristics of a single cylinder direct injection diesel engine with palm oil biodiesel and its blends. From their results, they reported that the acceptable $\backslash$ thermal efficiencies were obtained, and the specific fuel consumption and exhaust gas temperatures were higher than the results obtained with diesel fuel. Many investigations have been done on the utilization of biodiesel derived from different feed stock in diesel engine [20-22. From those work it can be pointed out that the selection of biodiesel is very important. The biodiesel derived from non-edible feed stock is always a better choice due to food security issue because use of edible oil as feed stock of biodiesel will affect this issue critically. The different non-edible feed stock used for production of biodiesel is Jatropha curcas, karanja, tobacco seed, rice bran, 
mahua, neem, rubber Plant, castor, linseed, and microalgae [23-24], etc. In this chapter application of biodiesel derived by Jatropha oil is described. The bio-diesel thus produced is blended with waste transformer oil at different volume proportions and tested in diesel engines.

\section{Fuel Preparation}

In the present study fuel was produced by transesterification process. The esterification process involves the reaction of a triglyceride (fat/oil) with alcohol in the presence of an alkaline catalyst such as sodium hydroxide. A triglyceride has a glycerine molecule as its base with three long fatty acids attached. The alcohol reacts with the fatty acids to form a mono-alkyl ester, or biodiesel, and crude glycerol, used in the cosmetic, pharmaceutical, food and painting industries. The alcohol used is usually either methanol, which produces methyl esters, or ethanol, with ethyl esters. The base applied for methyl ester is potassium or sodium hydroxide, but for ethyl ester the former base is more suitable. The esterification reaction is affected by the chemical structure of the alcohol, the acid and the acid catalyst.

The present study is aimed to analysis the effect of waste transformer oil (WTO) blended with Jatropha Methyl Ester (JME) in four different percentages as test fuels, on the performance and emission characteristics of a diesel engine. The WTO at low percentages (10-40\% at regular intervals of $10 \%$ on a volume basis), was blended with diesel, to get the fuel blends for the investigation. The designations of the test fuels and their compositions used in this study are given below.

\begin{tabular}{|c|c|c|c|}
\hline Fuel & $\begin{array}{c}\text { JME } \\
\text { (by volume) }\end{array}$ & $\begin{array}{c}\text { WTO } \\
\text { (by volume) }\end{array}$ & $\begin{array}{c}\text { Diesel } \\
\text { (by volume) }\end{array}$ \\
\hline diesel & - & - & $100 \%$ \\
\hline JME & $100 \%$ & - & - \\
\hline B10 & $90 \%$ & $10 \%$ & - \\
\hline B20 & $80 \%$ & $20 \%$ & - \\
\hline B30 & $70 \%$ & $30 \%$ & - \\
\hline B40 & $60 \%$ & $40 \%$ & - \\
\hline
\end{tabular}

\section{Experimentation}

The test was carried out on a single cylinder, four stroke, naturally aspirated, air cooled, DI diesel engine which has a maximum power out of $4.4 \mathrm{~kW}$. The test engine specifications are provided in Table 1 . For loading on the test engine an eddy current dynamometer is coupled to engine with the help of load cell. The engine is interfaced to a control panel, which is connected to a computer. The inputs obtained from different instruments are interfaced to a computer through an analog and digital converter card PCI1050 which is mounted on the motherboard. A data acquisition system (DAS) integrated with a computer received data from different instruments which is then processed and displayed on the monitor.

\section{Table 1 Engine specifications}

\begin{tabular}{|l|l|}
\hline \multicolumn{1}{|c|}{ Manufacturer } & \multicolumn{1}{c|}{ Kirloskar } \\
\hline Model & TAF 1 \\
\hline Engine type & Single cylinder, four stroke, constant speed, air cooled, direct injection, CI engine sp \\
\hline Rated power $(\mathrm{kW})$ & 4.4 \\
\hline Speed (rpm) & 1500 (constant) \\
\hline Bore $(\mathrm{mm})$ & 87.5 \\
\hline Stroke $(\mathrm{mm})$ & 110 \\
\hline Piston type & Bowl-in-piston \\
\hline Displacement volume $\left(\mathrm{cm}^{3}\right)$ & 661 \\
\hline Compression ratio & 17.5 \\
\hline Nozzle Opening pressure $(\mathrm{bar})$ & 200 \\
\hline Start of fuel injection & $23^{\circ} \mathrm{CA}$ bTDC (for diesel) \\
\hline Start of fuel injection & $24.5^{\circ} \mathrm{CA}$ bTDC (for JMETP020) \\
\hline Dynamometer & Eddy current \\
\hline Injection type & Pump-line-nozzle injection system \\
\hline Nozzle type & Multi hole \\
\hline No. of holes & 3 \\
\hline
\end{tabular}

\section{Results and Discussion}

This section discusses the results of the performance and emission parameters obtained from the test engine run on diesel, JME and different JME-WTO blends.

\subsection{Brake Thermal Efficiency}

The brake thermal efficiency gives information regarding how efficient the energy in the fuel was converted in to power output [25]. Figure 1 presents the power performance of the diesel and different test fuel blends derived engine under different loading conditions. It can be seen that under the same load, the greater efficiency is for diesel operated engine. In addition, the engine power increased linearly with the load for all the test fuels. As the load increases the heat generated in the cylinder increases, and hence, the brake thermal efficiency increases. At full load the diesel gave highest brake thermal efficiency compared to all the test fuels used in the present study. This can be pertained to the higher calorific value of the diesel fuel compared among all test fuel used.

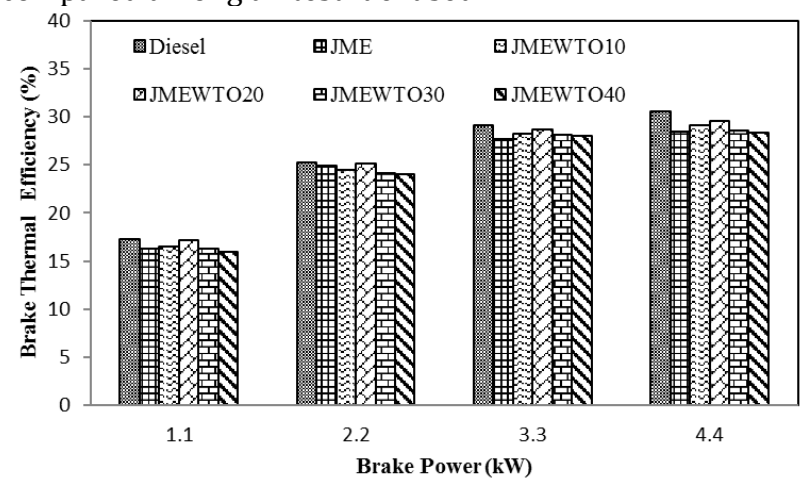

Fig.1 Variation of brake thermal efficiency with brake power 
The poor atomization of test fuels due to the higher viscosity may also be one of the causes for lower brake thermal efficiency than that of diesel. Among blends B20 produces highest brake thermal efficiency.

\subsection{Carbon Monoxide Emission}

The carbon monoxide (CO) emission characteristics of the engine run on diesel and different test fuel blends is presented in Fig. 2. It is known that the rate of $\mathrm{CO}$ emission is a function of the unburned fuel availability and mixture temperature, which controls the rate of fuel decomposition and oxidation. In the presence of sufficient oxygen, the CO emission is converted into carbon dioxide emission [26]. The value of $\mathrm{CO}$ emission at full load for the diesel, JME, B10, B10, $\mathrm{B} 15$ and B20 blend was found to be $0.044,0.035,0.037,0.04$, 0.046 and $0.052 \%$. The CO emission for the JME, B10 and B20 is marginally lower than those of diesel fuel. This could be due to the fact that JME contains excess oxygen which helps for better combustion. When the percentage of tire derived fuel increases beyond $10 \%$, the CO emission increases drastically. This may be due presence of aromatic content which results in incomplete combustion, and may lead to higher CO emission [27].

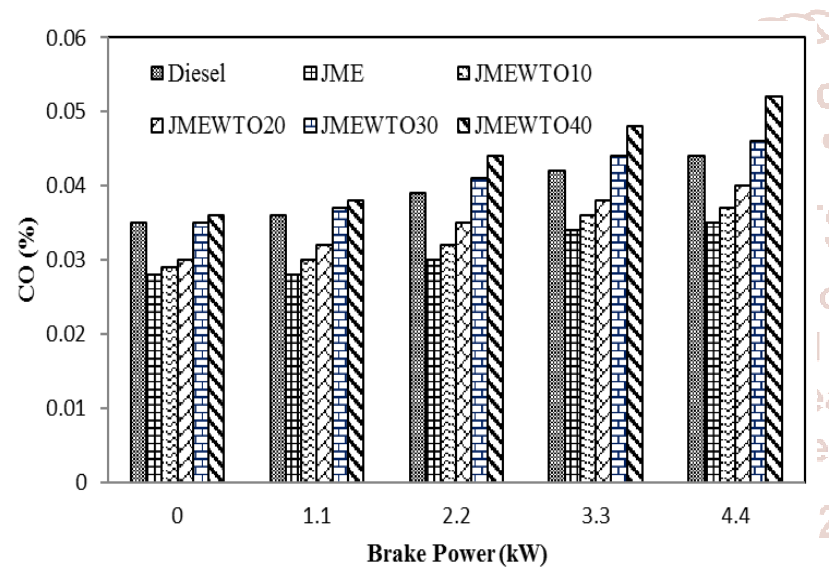

Fig.2 Variation of carbon monoxide emission with brake power

4.3 Hydrocarbon Emission

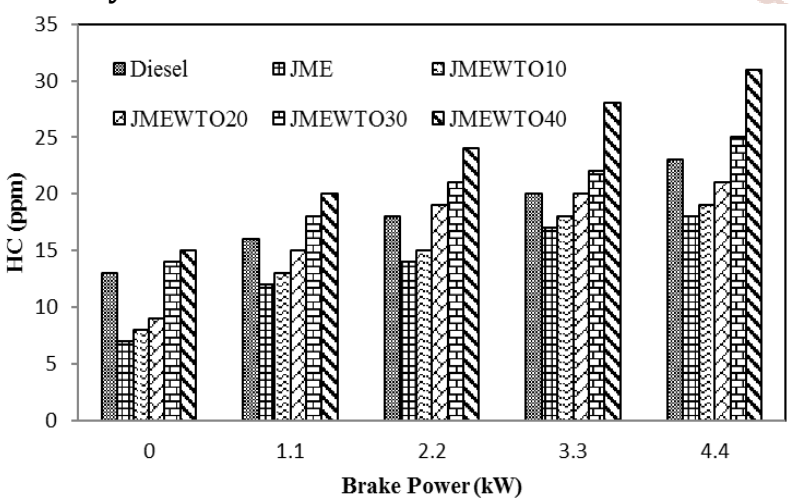

Fig.3 Variation of the unburnt hydrocarbon emission with brake power

The variation of hydrocarbon (HC) emission for diesel, JME and different test fuel blends is shown in Fig. 3. It is observed that hydrocarbon emission increases with the increase in percentage of WTO in the JME-WTO blends. The HC emission is lowest for JME and it was about $18 \mathrm{ppm}$ at full load operation. This can be due to oxygen molecule present in biodiesel [28]. The highest value of HC emission was obtained with B20 blend and was noticed to be $31 \mathrm{ppm}$. But the addition of the tire derived liquid percentage results in higher HC emission. This is due to the fact that TPO has higher aromatic content, and hence may result in incomplete combustion and more $\mathrm{HC}$ emission for B15 and B20 compared to the other test fuels used in this study. The HC values for diesel, JME, B10, B20, B30 and B40 are 23, 18, 19, 21,25 and $31 \mathrm{ppm}$ are at full load.

\subsection{Nitric Oxide Emission}

The nitric oxide (NO) emission characteristics of the diesel and different test fuel blends derived engine at different load conditions are presented in Fig.4. It can be seen that the NO emission concentration increased with the load for all the test fuels.

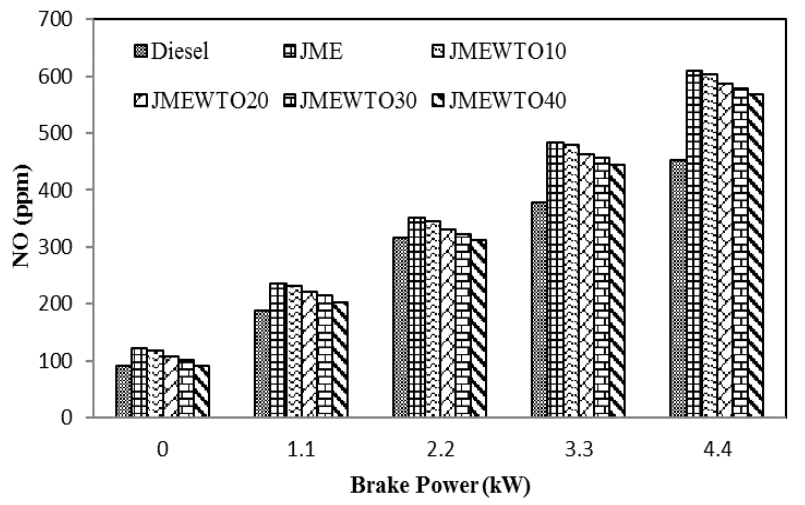

Fig.4 Variation of the nitric oxide emission with brake power

This is due to the fact that, because with increasing load, the temperature prevailing in the combustion chamber increases [29-30]. The NO emission form engine exhaust is highly dependent on oxygen concentration and combustion temperature. The JME has about $11 \%$ oxygen molecule which is the major cause of higher NO emission for this fuel compared to all other test fuel used in this study. While increasing the WTO percentage in the blend, the NO emission decreases, because of lower heat release rates than that of JME. The values of NO emission for diesel, JME, B10, B20, B30, and B40 are by about 452, 614, 589, 564, 549, and 532 ppm respectively, at full load operation.

\section{Conclusions}

A single cylinder, four stroke, naturally aspirated, air cooled, DI diesel engine was operated successfully using JME-WTO blends. The following conclusions are made based on the experimental results.

$>$ The brake thermal efficiency of the engine was highest for the diesel and among different blend B10 gave higher brake thermal efficiency. At full load, the brake thermal efficiency is almost the same, i.e., $29.9 \%$ and $30.8 \%$ for B20 and diesel respectively, at full load.

$>$ The CO and HC emissions were lower by about $9 \%, 19 \%$ respectively for B20, compared to diesel at full load.

$>$ Nitric oxide emission was higher by about $21 \%$ for B20 in comparison with diesel at full load.

$>$ On the whole it is concluded, that the B20 blend can be used as fuel in a diesel engine directly, without any engine modification. The B20 gives the optimum result, compared to the other blends. The results from the experiments prove that B20 blend is good substitute for diesel fuel. 


\section{References}

[1] International Energy Agency. Energy and Air Pollution. 2016. Doi: $10.1021 /$ ac00256a010.

[2] BP Energy Outlook - 2016 edition. 2016.

[3] IPCC 2014. Climate Change 2014: Synthesis Report. Contribution of Working Groups I, II and III to the Fifth Assessment Report of the Intergovernmental Panel on Climate Change. IPCC, Geneva, Switzerland: 2014.

[4] Wu, H. W., Wang, R. H., Ou, D. J., Chen, Y. C., \& Chen, T. Y. (2011). Reduction of smoke and nitrogen oxides of a partial HCCI engine using premixed gasoline and ethanol with air. Applied Energy, 88(11), 3882-3890.

[5] Vehicular Pollution - water, effects, environmental, pollutants, impact, EPA, chemicals, toxic, human, power, sources, use, life, health, oil 2016. http://www.pollutionissues.com/Ve-Z/VehicularPollution.html (accessed August 29, 2016).

[6] Dieselnet. EU Emission Standards for Passenger Cars n.d.https://www.dieselnet.com/standards/eu/ld.php (accessed July 6, 2018).

[7] Kumar, M. S., Ramesh, A., \& Nagalingam, B. (2001). Investigations on the use of Jatropha oil and its methyl ester as a fuel in a compression ignition engine. Journal of the Institute of Energy, 74(498), 24-28.

[8] Kumar, M. S., Ramesh, A., \& Nagalingam, B. (2003). An experimental comparison of methods to use methanol and Jatropha oil in a compression ignition engine. biomass and bioenergy, 25(3),309-318.

[9] Sahoo, P. K., Naik, S. N., \& Das, L. M. (2005). Studies on biodiesel production technology from jatropha curcas and its performance in a CI engine. Journal of Agricultural Engineering, 42(2), 14-20.

[10] Mandpe, S., Kadlaskar, S., Degen, W., \& Keppeler, S. (2005). On road testing of advanced common rail diesel vehicles with biodiesel from the Jatropha curcas plant (No. 2005-26-356). SAE Technical Paper.

[11] Mahanta, P., Mishra, S., \& Kushwah, Y. (2006). A comparative study of pongamia pinnata and jatropha curcus oil as diesel substitute. International Energy Journal, 7(1).

[12] Sivaprakasam, S., \& Saravanan, C. G. (2007). Optimization of the transesterification process for biodiesel production and use of biodiesel in a compression ignition engine. Energy \& Fuels, 21(5), 2998-3003.

[13] Lakshmi Narayana Rao, G., Durga Prasad, B., Sampath, S., \& Rajagopal, K. (2007). Combustion analysis of diesel engine fueled with jatropha oil methyl esterdiesel blends. International Journal of Green Energy, $4(6), 645-658$.

[14] Sher E. Handbook of air pollution from internal combustion engines: pollutant formation and control. Academic Press; 1998 Mar 20.

[15] Chiaramonti D, Oasmaa A, Solantausta Y. Power generation using fast pyrolysis liquids from biomass. Renewable and sustainable energy reviews. 2007 Aug 31; 11(6):1056-86.
[16] Mohan D, Pittman CU, Steele PH. Pyrolysis of wood/biomass for bio-oil: a critical review. Energy \& fuels. 2006 May 17;20(3):848-89.

[17] Chen Y, Cheng JJ, Creamer KS. Inhibition of anaerobic digestion process: a review. Bioresource technology. 2008 Jul 31;99(10):4044-64.

[18] Ladisch MR, Lin KW, Voloch M, Tsao GT. Process considerations in the enzymatic hydrolysis of biomass. Enzyme and Microbial technology. 1983 Mar 1;5(2):82102.

[19] Verma P, Zare A, Jafari M, Bodisco TA, Rainey T, Ristovski ZD, Brown RJ. Diesel engine performance and emissions with fuels derived from waste tyres. Scientific reports. 2018 Feb 6;8(1):2457.

[20] Siva M, Onenc S, Uçar S, Yanik J. Influence of oily wastes on the pyrolysis of scrap tire. Energy conversion and management. 2013 Nov 1; 75:474-81.

[21] Duan P, Jin B, Xu Y, Wang F. Co-pyrolysis of microalgae and waste rubber tire in supercritical ethanol. Chemical Engineering Journal. 2015 Jun 1; 269:262-71.

[22] Dincer K. Lower emissions from biodiesel combustion. Energy Sources, Part A. 2008 Mar 27;30(10):963-8.

[23] Sigar CP, Soni SL, Mathur J, Sharma D. Performance and emission characteristics of vegetable oil as diesel fuel extender. Energy Sources, Part A: Recovery, Utilization, and Environmental Effects. 2008 Dec 2;31(2):139-48.

[24] Balat M, Balat M, Kırtay E, Balat H. Main routes for the thermo-conversion of biomass into fuels and chemicals. Part 1: Pyrolysis systems. Energy Conversion and Management. 2009 Dec 1;50(12):3147-57.

[25] Jull C, Redondo PC, Vapnek J. Recent trends in the law and policy of bioenergy production, promotion and use. Food \& Agriculture Org.; 2007.

[26] Kannan M, Karthikeyan R, Deepanraj B, Baskaran R. Feasibility and performance study of turpentine fueled DI diesel engine operated under HCCI combustion mode. Journal of Mechanical Science and Technology. 2014 Feb 1; 28(2):729-37.

[27] Prakash R, Singh RK, Murugan S. An experimental investigation on a diesel engine fueled by biodiesel and its emulsions with wood pyrolysis oil. International journal of green energy. 2012 Nov 1;9(8):749-65.

[28] Lima DG, Soares VC, Ribeiro EB, Carvalho DA, Cardoso ÉC, Rassi FC, Mundim KC, Rubim JC, Suarez PA. Diesellike fuel obtained by pyrolysis of vegetable oils. Journal of Analytical and Applied Pyrolysis. 2004 Jun 1; 71(2):987-96.

[29] Demirbaş A. Biodiesel fuels from vegetable oils via catalytic and non-catalytic supercritical alcohol transesterifications and other methods: a survey. Energy conversion and Management. 2003 Aug 1; 44(13):2093-109.

[30] Schuchardt U, Sercheli R, Vargas RM. Transesterification of vegetable oils: a review. Journal of the Brazilian Chemical Society. 1998 May;9(3):199210 . 